\title{
Diversity, host, and habitat specificity of oomycete communities in declining reed stands (Phragmites australis) of a large freshwater lake
}

\author{
Jan NECHWATAL*, Anna WIELGOSS, Kurt MENDGEN \\ Universität Konstanz, Phytopathology, D-78457 Konstanz, Germany
}

\section{A R T I C L E I N F O}

\section{Article history:}

Received 26 June 2007

Received in revised form

16 October 2007

Accepted 29 November 2007

Corresponding Editor:

David L. Hawksworth

Keywords:

Ecology

Natural ecosystem

Phytophthora

Pythium

Reed dieback

\begin{abstract}
A B S T R A C T
We studied the diversity of oomycetes in a declining reed belt (Phragmites australis) of Lake Constance, Germany, using conventional baiting with specific reed and standard oak baits, accompanied by molecular techniques. Apart from an Aphanomyces sp. and a Phytophthora sp., baiting from reed rhizosphere samples from flooded, as well as drier, littoral sites revealed only Pythium spp. A total of 67 oomycete isolates was classified according to PCR-RFLP banding patterns and ITS sequencing, and 18 different sequence types could be separated. The majority of these seemed previously unknown species, as indicated by the degree of similarity to those deposited in nucleotide databases. Species communities in both flooded and drier habitats or both reed and oak baits clearly differed from one another, and only few species occurred in both dry and flooded sites, or in both oak and reed baits. A frequently occurring group of related Pythium species appeared to be specifically associated with reed, and these were the only species that proved pathogenic towards this host in vitro. Our study proved that unexplored natural ecosystems harbour diverse communities of oomycete species with specific habitat and host preferences within close-by, but ecologically contrasting, sites. Among the species isolated, those associated with the predominating plant might accumulate and thus may be reed pathogens of considerable importance.
\end{abstract}

\section{Introduction}

The oomycetes (Peronosporomycetes) is a group of fungus-like organisms that, although ecologically and physiologically similar to true fungi is considered to belong to the kingdom of Straminipila, unrelated to the Eumycota (Cavalier-Smith 1998; Dick 2001). Several oomycete genera are known as economically significant pathogens of numerous agricultural or horticultural plants, with the most important being the downy mildews, Pythium, Phytophthora, and Aphanomyces. Other taxa infect fish, insects and mammals (Hendrix \& Campbell 1973; van der Plaats-Niterink 1981; Dick 2001). By contrast, many oomycete species are not known to be pathogens, either due to the lack of knowledge on the respective taxa, or due to their strictly saprotrophic lifestyle (van der Plaats-Niterink 1981; Martin 1992; Dick 2001).

In the past decade, a significant increase in interest in soil- and waterborne oomycete pathogens of plants other than agricultural crops has been observed. In particular, Phytophthora communities of diverse natural ecosystems were investigated in several studies (e.g. Brasier \& Jung 2003). Much knowledge has also accumulated on the involvement

\footnotetext{
* Corresponding author.

E-mail address: jan.nechwatal@uni-konstanz.de
} 
of Pythium spp. in plant diseases or seedling losses of 'wild' plants, or their potential influence on natural plant community composition (e.g. Mills \& Bever 1998; Packer \& Clay 2000, 2004; Nechwatal \& Osswald 2001). Host-specific accumulation of Pythium species was shown to occur in the soil beneath certain plant species and, due to negative feedback effects on growth, Pythium soil pathogens are believed to contribute to species diversity within plant communities (Packer \& Clay 2000; Mills \& Bever 1998). Supported by molecular evidence, several new oomycete species, mostly Pythium and Phytophthora, from natural and non-agricultural ecosystems have been described recently (e.g. Brasier \& Jung 2003; Nechwatal \& Osswald 2003; Paul 2003). Accordingly, the current estimates of ca 120 Pythium and 70 Phytophthora species (Dick 2001) by far underestimate the true diversity within these genera. Studies of largely unexplored non-agricultural ecosystems, and the accompanying use of molecular identification tools, such as PCR-RFLP and sequencing, are likely to reveal large numbers of 'new', undescribed oomycete species, with yet unknown functions, capabilities or host ranges.

The common reed (Phragmites australis), a large perennial grass with worldwide distribution, is a major component of wetland and littoral plant communities of many freshwater ecosystems. It usually forms large natural monocultures at the land-water interface with several important ecological functions (Haslam 1972). European freshwater reed belts have been suffering from major decline events during the past 50 y (Brix 1999), and due to their aquatic or semi-aquatic nature are likely to harbour large numbers of yet unknown oomycete species, as these are often associated with moist, flooded, or water-logged soil conditions. They may play a major role in the breakdown of plant litter, but may also be reed pathogens of considerable significance, such as the recently described Pythium phragmitis (Nechwatal et al. 2005). We investigated the oomycete community, particularly the genus Pythium, in declining reed stands of Lake Constance, Germany, using a traditional baiting approach supplemented by molecular identification methods. This study describes diversity, habitat preferences, and pathogenicity of oomycetes in a natural ecosystem, largely undisturbed by agricultural activity, and adds new aspects to the discussion on possible causes and aetiology of reed decline.

\section{Materials and methods}

\section{Baiting}

Soil samples for the isolation of oomycetes were taken from the rhizosphere of Phragmites australis growing in the reed belt of the Lake Constance littoral between April and September 2003. The sampling site is located on the shore of Bodan peninsula close to a nature reserve $\left(9^{\circ} 11^{\prime} 20^{\prime \prime} \mathrm{E}\right.$, $47^{\circ} 41^{\prime} 48^{\prime \prime} \mathrm{N}$ ), and lined by mixed alluvial forests. In total, 14 soil samples were taken during the sampling period from permanently flooded $(n=8)$ and from drier, i.e. only occasionally flooded sites $(n=6)$ along an approx. 50 m strip within the extension of the littoral reed belt. At each occasion (April, May, June, August, September), samples from both habitat types were taken. Samples were subjected to a bait test using a presumably specific (young reed leaves, greenhouse plants) and a more standard bait (oak leaflets, Quercus robur, greenhouse plants). Oak baits have been previously shown to be able to isolate a large variety of oomycete genera from different natural soils (e.g. Jung et al. 1996; Newell \& Fell 1996; Nechwatal \& Osswald 2001, 2003; Nechwatal \& Mendgen 2006a, b). Soil samples were flooded with deionised water, and several baits were spread over the water surface. Infected baits, showing discolouration after ca $3-5 \mathrm{~d}$ of incubation at $19^{\circ} \mathrm{C}$, were cut into small segments and plated onto a selective agar medium consisting of V8 agar (as given below), amended with $25 \mathrm{mgl}^{-1}$ Benomyl (Dupont, Bad Homburg, Germany), $50 \mathrm{mgl}^{-1}$ pentachloronitrobenzene, $10 \mathrm{mgl}^{-1}$ rifampicin, $200 \mathrm{mgl}^{-1}$ ampicillin (all from Sigma-Aldrich, Taufkirchen, Germany). Plates were incubated at $19^{\circ} \mathrm{C}$ in the dark. Developing colonies were subcultured, purified from bacterial contaminants and transferred to V8 agar plates (V8A, $100 \mathrm{ml}$ V8 juice, $16 \mathrm{~g}$ agar, $3 \mathrm{~g} \mathrm{CaCO}_{3}, 900 \mathrm{ml}$ distilled $\mathrm{H}_{2} \mathrm{O}$ ) for further identification and maintenance.

\section{Species characterisation and identification}

Preliminary identification and classification of the recovered isolates to genus or species level was based on mycelial growth rate, sporangial and oogonial shape with the aid of the keys and monographs of Waterhouse (1968), van der Plaats-Niterink (1981) and Dick (1990). For molecular identification, DNA from mycelial material scraped off from agar plates was extracted using the DNeasy Plant Mini Kit (Qiagen, Hilden, Germany). PCR amplification of rDNA ITS regions was performed with primer pair ITS4 and ITS6 (White et al. 1990; Cooke \& Duncan 1997). The enzymes AluI, HinfI, MspI and TaqI (Fermentas, St Leon-Roth, Germany) were used for digesting the amplicons in a total volume of $20 \mu$ l. DNA fragments were separated on $3 \%$ agarose gels. The resulting banding patterns allowed the isolates to be separated into groups of identical patterns (RFLP types). Direct sequencing of the PCR products of selected isolates of each of the RFLP types was carried out by MWG Biotech (Martinsried). Forward and reverse strand sequences were aligned, ambiguous signals checked manually, and sequences trimmed to comprise complete ITS1, 5.8S and ITS2 regions only. BLAST searches of the GenBank nucleotide database were performed to find the most closely related species. In cases where several isolates from a given soil sample turned out to be identical according to RFLP banding patterns and ITS sequences, these were counted as one isolate only.

Selected isolates of each of the RFLP types were characterised in detail as to their morphology. Isolates were grown on V8A plates for at least $6 \mathrm{~d}$, and a minimum of 25 diagnostic structures (oospores, oogonia, sporangia, hyphal swellings etc.) were measured at $\times 400$ magnification using a light microscope. Data were confirmed in random checks within all isolates of a particular RFLP type. For the assessment of growth rates all isolates were subcultured onto V8A plates $(20 \mathrm{ml})$, and incubated at $25^{\circ} \mathrm{C}$ after the onset of hyphal growth. Growth was recorded daily for $3 \mathrm{~d}$ along two straight axes drawn from the inoculation plug, and values averaged. Colony patterns were assessed after at least $6 \mathrm{~d}$ growth on $2 \%$ malt 
extract agar (MEA). All isolates are stored at the Konstanz University/Phytopathology culture collection.

\section{Phylogenetic analysis}

Sequences of each Pythium taxon from this study and those of each of their closest relatives (reference taxa from GenBank) were aligned using ClustalW implemented in the BioEdit package (http://www.mbio.ncsu.edu/BioEdit/bioedit.html). Complete ITS1, 5.8S, and ITS2 sequences were used for phylogenetic studies, Aphanomyces was not included in the alignment. Genetic distances among isolates and NJ trees were calculated using DNADIST and NEIGHBOR from the PHYLIP package (v3.57c, Felsenstein 1995). Tree topology was confirmed in $1 \mathrm{~K}$ BS replicates using SEQBOOT and CONSENSE (Felsenstein 1995). Trees were drawn using NJplot (Perrière \& Gouy 1996).

\section{Community comparison}

To compare species diversity in bait-derived oomycete communities, the Shannon-Wiener and Simpson indices were calculated and compared using the program Species Diversity and Richness v. 3.03 (Pisces Conservation Ltd., Lymington). Average sequence divergence $\left(\theta_{\pi}\right)$ was calculated using Arlequin 2.000 (Schneider et al. 2000). Aligned complete ITS1, $5.8 \mathrm{~S}$, and partial ITS2 sequences for each taxon obtained during this study and their relative frequencies were used for analysis, without the addition of reference taxa. The degree of differentiation between communities from dry and flooded sites, or from reed and oak baits, respectively, was estimated by computing $\mathrm{F}_{\mathrm{st}}$ statistics using Arlequin. Methods for molecular diversity calculation have been described by Martin (2002) and Arcate et al. (2006).

\section{Pathogenicity}

Mature, greenhouse-grown reed (Phragmites australis) leaves were used to test the potential pathogenicity of the oomycete isolates towards this host. For each isolate, seven leaves of approximately the same age (i.e. the same position on the culm) were collected, clipped on base and apex to a length of ca 10$12 \mathrm{~cm}$, and placed in glass Petri dishes containing moist filter paper. Leaf blades were inoculated centrally with a disc $(4 \mathrm{~mm}$ diam) taken from the margin of an actively growing culture of each of the RFLP types/oomycetes tested. A drop of a $0.05 \%$ skimmed milk solution was applied to the agar disc to facilitate adhesion to the leaf surface. Controls received uncolonised V8A plugs. Leaf lesion development was recorded after $6 \mathrm{~d}$ of incubation at $19^{\circ} \mathrm{C}$. Experiments were conducted in duplicate for each species.

\section{Results}

\section{Baiting, species characterisation, and identification}

Baiting from 14 reed soil samples with oak and reed baits revealed a total of 54 Pythium isolates, 11 isolates of an undescribed, presumably sterile Phytophthora sp. (Nechwatal \&
Mendgen 2006b), and two isolates of an Aphanomyces with spiny oogonia. One to seven individual oomycete isolates were obtained from a single soil sample. RFLP and sequencing analysis of the ITS1 and ITS2 regions suggested that the oomycete isolates belonged to 18 different taxa, of which a majority of 16 were Pythium (Table 1). After restriction analysis with up to four enzymes and subsequent sequencing of one or more RFLP type representatives all isolates could unambiguously be assigned to a given taxon. Despite only minor sequence differences between some of the proposed taxa and low BS support for some of the outer branches (Fig 1), morphological studies confirmed our molecular classification scheme and taxa were tentatively given 'species' rank for all subsequent analyses. Morphological data of the species isolated are summarised in Table 2. Multiple isolations of the same taxon per soil sample could subsequently be eliminated, resulting in 48 different oomycete isolates. From oak baits, 33 isolates (13 species) were obtained, whereas reed baits caught 15 isolates (eight species). The most abundant species from dry sites was Pythium type III ( $22 \%$ of all isolates), in flooded sites Pythium type X-c and Phytophthora sp. were predominant (17 \%).

BLAST searches with the ITS sequences generated during this study revealed that most of the oomycetes were undescribed species or not available in public sequence databases. Only four of the 18 taxa could unambiguously be assigned to known species, i.e. were $100 \%$ identical to one or more respective database entries. Sequence identities of the other isolates to known taxa ranged from 88-99\% (Table 1).

The majority of Pythium taxa from flooded sites (73\%) belonged to species from clades $\mathrm{A}$ and $\mathrm{B}$ of Lévesque \& De Cock (2004), i.e. had filamentous sporangia, whereas from dry sites, only $44 \%$ had sporangia of this type. Pythium isolates from clade B1 (types X-a, X-b, X-c, XIV) all were members of the grass-associated clusters B1d and B1e (Lévesque \& De Cock 2004), and were among the dominating in both habitat types (dry: $22 \%$, flooded: $24 \%$ of all isolates). Unlike all other species, these types were exclusively isolated from reed baits, not from oak baits (Table 1 ). Type X-c was recently described as P. phragmitis sp. nov. (Nechwatal et al. 2005), and type X-b is considered to be a hybrid between $P$. phragmitis and a species close to P. arrhenomanes (Nechwatal \& Mendgen 2007). Most isolates from clade B2 (types I, I-a, I-b, VI, VII-a) were closely related and close to the $P$. dissotocum/P. lutarium complex, with identities of ca $97 \%$. The frequently occurring type III, as well as types V, VIII and XII from clade K were only distantly related to any other species in that clade. Type III was recently described as P. litorale sp. nov. (Nechwatal \& Mendgen 2006a). Phylogenetic positioning and clade affiliations of the Pythium species from this study and their closest relatives as indicated by ITS sequences is shown in Fig 1.

\section{Community comparison}

Of the 18 species recovered from soil samples, only four occurred in both habitats, four were recovered exclusively from dry, ten from flooded sites. Similarly, the community baited with reed was different from that baited with oak leaves, with only three species isolated from both bait types (Tables 1 and 3). Comparing species diversity indices, bait communities from flooded sites and from oak baits were 
Table 1 - Composition, clade affiliation, habitat, and bait type of oomycete species communities from reed sites as revealed by baiting techniques

\begin{tabular}{|c|c|c|c|c|c|c|c|c|c|}
\hline \multirow{2}{*}{$\begin{array}{l}\text { Type/ } \\
\text { species }^{a}\end{array}$} & \multirow{2}{*}{$\begin{array}{l}\text { Genus/ } \\
\text { Pythium } \\
\text { clade }^{\mathrm{b}}\end{array}$} & \multirow{2}{*}{$\begin{array}{l}\text { Sporangial } \\
\text { type }^{c}\end{array}$} & \multicolumn{2}{|c|}{ No. of isolates } & \multicolumn{2}{|c|}{ No. of isolates } & \multirow{2}{*}{$\begin{array}{c}\text { Closest BLAST } \\
\text { hit (ITS) }\end{array}$} & \multirow{2}{*}{$\begin{array}{l}\text { Identity } \\
\qquad \%)\end{array}$} & \multirow{2}{*}{$\begin{array}{c}\text { GenBank } \\
\text { accession } \\
\text { no. }\end{array}$} \\
\hline & & & $\begin{array}{c}\text { From dry } \\
\text { sites } \\
\left(\sum=18\right)\end{array}$ & $\begin{array}{l}\text { From } \\
\text { flooded } \\
\text { sites } \\
\left(\sum=30\right)\end{array}$ & $\begin{array}{l}\text { From oak } \\
\left(\sum=33\right)\end{array}$ & $\begin{array}{c}\text { From } \\
\text { reed } \\
\left(\sum=15\right)\end{array}$ & & & \\
\hline I & B2 & $\mathrm{F}$ & 2 & 3 & 4 & 1 & Pythium dissotocum/lutarium & 97.3 & DQ230902 \\
\hline $\mathrm{I}-\mathrm{a}$ & B2 & $\mathrm{F}$ & 1 & 0 & 1 & 0 & P. dissotocum/lutarium & 97.3 & DQ230903 \\
\hline $\mathrm{I}-\mathrm{b}$ & B2 & $\mathrm{F}$ & 0 & 1 & 1 & 0 & P. dissotocum/lutarium & 97.2 & DQ230904 \\
\hline II & $\mathrm{F}$ & HS & 2 & 0 & 2 & 0 & P. intermedium & 100 & DQ232765 \\
\hline III & $\mathrm{K}$ & G & 4 & 3 & 7 & 0 & P. litorale $e^{\mathrm{d}}$ & 100 & DQ144637 \\
\hline IV & $\mathrm{J}$ & G & 3 & 0 & 3 & 0 & P. perplexum & 100 & DQ232766 \\
\hline V & $\mathrm{K}$ & G & 0 & 1 & 1 & 0 & P. helicoides & 88.5 & DQ232768 \\
\hline VI & B2 & $\mathrm{F}$ & 0 & 2 & 2 & 0 & P. dissotocum/lutarium & 97.6 & DQ232767 \\
\hline VII-a & B2 & $\mathrm{F}$ & 0 & 3 & 2 & 1 & P. aquatile & 96.7 & DQ235226 \\
\hline VIII & $\mathrm{K}$ & G & 0 & 1 & 1 & 0 & P. helicoides & 92.6 & DQ235227 \\
\hline $\mathrm{X}-\mathrm{a}$ & B1e & F-I & 1 & 0 & 0 & 1 & P. arrhenomanes & 100 & AY743661 \\
\hline $\mathrm{X}-\mathrm{b}$ & B1e & F-I & 3 & 1 & 0 & 4 & P. phragmitis ${ }^{\mathrm{d}}$ & 99.4 & AY594258 \\
\hline $\mathrm{X}-\mathrm{c}$ & B1e & F-I & 0 & 5 & 0 & 5 & P. phragmitis ${ }^{d}$ & 100 & AY594259 \\
\hline XII & $\mathrm{K}$ & G & 0 & 1 & 1 & 0 & P. citrinum & 88.4 & DQ237932 \\
\hline XIII & A & $\mathrm{F}$ & 0 & 1 & 0 & 1 & P. porphyrae & 99 & DQ237933 \\
\hline XIV & B1d & F-I & 0 & 1 & 0 & 1 & P. inflatum & 99.6 & DQ237934 \\
\hline A & Aphanomyces & - & 0 & 2 & 1 & 1 & A. cladogamus & 93.8 & DQ861921 \\
\hline $\mathrm{Ph}$ & Phytophthora & - & 2 & 5 & 7 & 0 & P. taxon 'salixsoil' & 100 & AY762973 \\
\hline $\begin{array}{l}\text { a As rever } \\
\text { b Pythium } \\
\text { c Sporang } \\
\text { d Species }\end{array}$ & $\begin{array}{l}\text { led by analysi } \\
\text { clades after Lé } \\
\text { ial types in Pyt } \\
\text { recently descri }\end{array}$ & $\begin{array}{l}\text { of the ITS1, } 5 \\
\text { resque \& De C } \\
\text { ium: F, filame } \\
\text { ped (Nechwat }\end{array}$ & $\begin{array}{l}\text { 8S and ITS2 } \\
\text { ock (2004). } \\
\text { atous; F-I, fil } \\
\text { let al. 2005; }\end{array}$ & egion of th & $\begin{array}{l}\text { llated; G, g } \\
\text { Mendgen }\end{array}$ & $\begin{array}{l}\text { o6e, ovoi } \\
\text { 06a). }\end{array}$ & or pyriform; HS, hyphal swe & gs. & \\
\hline
\end{tabular}

significantly more diverse than those from dry sites, or reed baits, respectively.

Molecular diversity indices (mean sequence divergence $\theta_{\pi}$ ) of bait communities were largely similar in dry and flooded sites, and according to $F_{\text {st }}$ statistics, communities did not differ significantly. In contrast, the community from oak baits was more diverse than from reed, and both were significantly different as expressed by $\mathrm{F}_{\mathrm{st}}$ statistics (Table 3).

\section{Pathogenicity}

Only species from the grass-associated clusters B1d and B1e were pathogenic towards mature reed leaves (Table 2). Pythium phragmitis and Pythium type X-b caused the most extensive lesions, those caused by $P$. arrhenomanes $(\mathrm{X}-\mathrm{a})$ and Pythium type XIV were somewhat smaller. The isolate of type VII-a (clade B2) caused minor lesions on some leaves. None of the other species tested or the control inoculations caused damage to the leaves.

\section{Discussion}

The past decade has brought much new insight into the role of oomycetes in natural and semi-natural ecosystems. Mainly Phytophthora, but also Pythium spp., were shown to be significant pathogens of numerous woody and non-woody plant species on a worldwide scale (e.g. Packer \& Clay 2000; Brasier \& Jung 2003). In this study, we investigated community structure and pathogenicity of oomycetes, particularly the genus
Pythium, in non-agricultural ecosystems, as exemplified by the analysis of the reed belt of a large pre-alpine lake in Germany, which has been reported to be in decline for about five decades.

As was expected from the (semi-)aquatic nature of the investigated sites, the study revealed large numbers of undescribed oomycete species, of which the majority were Pythium spp. These results contradict the common textbook view that, although debatable, considers non-cultivated sites to be relatively poor in Pythium species (van der Plaats-Niterink 1981). Out of 18 species isolated, only four could unambiguously be assigned to already described species. Two more taxa have recently been described as new species (Nechwatal et al. 2005; Nechwatal \& Mendgen 2006a). As reed belts are largely unexplored ecosystems regarding their oomycete community, the high number of species new to science does not come as a surprise. A number of studies in previously unexplored natural ecosystems have also revealed several undescribed Pythium species (e.g. Nechwatal \& Osswald 2003; Paul 2003; Romero et al. 2007), as well as oomycetes from the Saprolegniaceae (e.g. Dick 1971). Consistent with the close association of soilborne oomycetes with moist or flooded sites, oomycete communities from flooded soils were significantly more diverse than those from drier sites in our study (Table 3). As also shown before (Lévesque \& De Cock 2004; Nechwatal \& Mendgen 2006a), Pythium clade $\mathrm{K}$, in particular, proved to be a source of new and highly divergent unknown species (Table 1).

Oak leaves have originally been used as baits in studies on the decline of oak, and highly diverse Phytophthora communities were consistently isolated using these baits (e.g. Jung et al. 


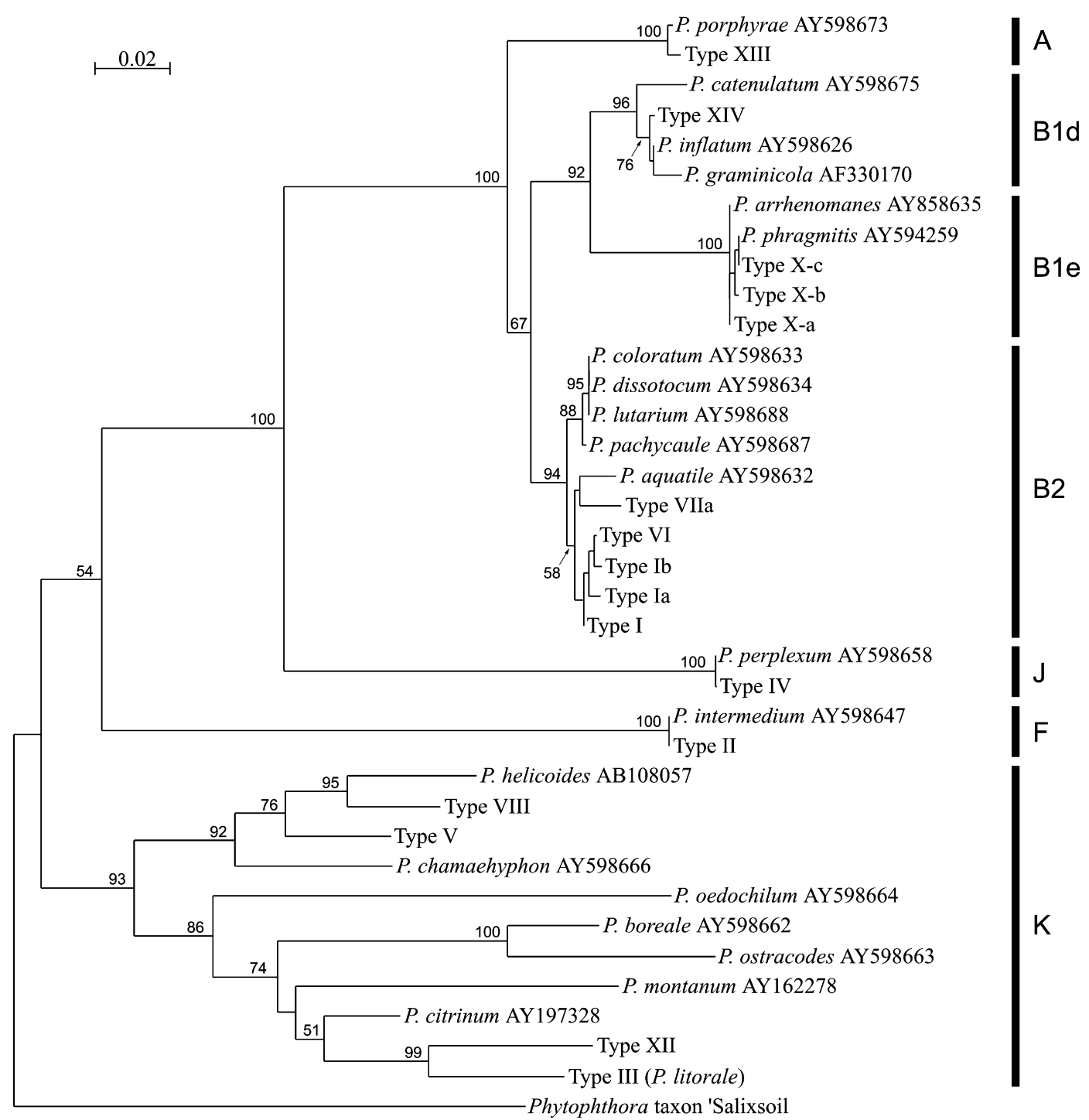

Fig 1 - NJ phylogenetic tree of Pythium spp. detected by isolation from baits (Roman numerals), and their closest GenBank matches, constructed after distance-based analysis of ITS1, 5.8S and ITS2 regions of the rDNA. Numbers at the branches indicate the percentage of BS values after $1 \mathrm{~K}$ replications (values below $50 \%$ not shown). Phytophthora taxon 'Salixsoil' from this study was used as outgroup. Bar = number of nucleotide substitutions per site. The bars on the right margin indicate phylogenetic clades according to Lévesque \& De Cock (2004).

1996). The choice was obviously based on the assumption that first evidence for the association of a particular oomycete with a specific host plant can be obtained using baiting material of the host under investigation. However, oak baits were also shown to be able to isolate large sets of Phytophthora, Pythium, Saprolegnia, and Achlya spp. from other natural ecosystems (Newell \& Fell 1996; Nechwatal \& Osswald 2001, 2003; Nechwatal \& Mendgen 2006a, b; J.N. unpubl.). The diversity of species isolated in our study again confirmed that oak leaves are suitable as a standard bait, revealing highly diverse sets of oomycete genera and species (Table 3). However, oak baits were obviously not able to detect the set of grass-associated species. This indicates the specific bias brought about by the bait plants used in a particular study, and we cannot exclude the possibility that more taxa would have been found with additional bait tissues/plants. However, we believe that by using an established standard and a specific (reed) bait, a significant fraction of the species present should have been recovered.

Relatively quick changes in species dominance and composition have been observed for Pythium communities (e.g. Hardman \& Dick 1987), rendering single-year, single-site studies somewhat uncertain. Nevertheless, although representing only a small fraction in both space and time, the approach applied in our study revealed well-defined habitat or substrate preferences for most of the species detected, consistent with the specific site properties, and indicating that the patterns observed were not merely by chance. Preferences of the taxa were clear-cut, with low levels of species overlap between communities occurring in both habitats or 


\begin{tabular}{|c|c|c|c|c|c|c|c|c|c|c|c|c|}
\hline $\begin{array}{l}\text { Species/ } \\
\text { group }\end{array}$ & $\begin{array}{l}\text { Pythium } \\
\text { clade }\end{array}$ & $\begin{array}{c}\text { Sporangial } \\
\text { type } \\
\text { (Pythium) }^{\mathrm{a}}\end{array}$ & $\begin{array}{l}\text { Oogonia } \\
\text { diam } \\
(\mu \mathrm{m})^{b}\end{array}$ & Antheridia $^{a}$ & $\begin{array}{l}\text { Oospore } \\
\text { diam } \\
(\mu \mathrm{m})^{b}\end{array}$ & $\begin{array}{l}\text { Oospore } \\
\text { state }\end{array}$ & $\begin{array}{c}\text { Oospore } \\
\text { wall }(\mu \mathrm{m})\end{array}$ & $\begin{array}{l}\text { Growth rate } \\
\left(25^{\circ} \mathrm{C}, \text { V8a) }\right. \\
\left(\mathrm{mm} \mathrm{d}^{-1}\right)^{\mathrm{b}}\end{array}$ & $\begin{array}{l}\text { Colony } \\
\text { pattern } \\
\text { (MEA) }\end{array}$ & Pathogenicity ${ }^{c}$ & $\begin{array}{l}\text { Voucher } \\
\text { material }^{\mathrm{d}}\end{array}$ & $\begin{array}{c}\text { Closest } \\
\text { BLAST hit (ITS) }\end{array}$ \\
\hline $\mathrm{I}-\mathrm{b}$ & B2 & $\mathrm{F}$ & $21(\mathrm{n} / \mathrm{a})$ & $\mathrm{m} / \mathrm{d}$ & $17(\mathrm{n} / \mathrm{a})$ & a & 2.5 & $20.3(\mathrm{n} / \mathrm{a})$ & None & - & UKN P33 & P. dissotocum \\
\hline II & $\mathrm{F}$ & HS & - & - & - & - & - & $30.5(3.5)$ & None & - & UKN P2 & P. intermedium \\
\hline III & $\mathrm{K}$ & G & - & - & - & - & - & $14.7(0.7)$ & Rosaceous & - & CBS 118360 & P. litorale \\
\hline IV & J & G & $21.5(1.02)$ & $\mathrm{h}$ ? & $19.5(1.1)$ & $\mathrm{a}$ & 2 & $15.3(1.5)$ & Faint radiate & - & UKN P5 & P. perplexum \\
\hline VII-a & B2 & $\mathrm{F}$ & - & - & - & - & - & $15.3(2.6)$ & None & + & UKN P23 & P. aquatile \\
\hline VIII & $\mathrm{K}$ & G & $30.5(\mathrm{n} / \mathrm{a})$ & $d(m)$ & $27.5(\mathrm{n} / \mathrm{a})$ & $\mathrm{a}$ & $<2$ & n.d. & None & - & UKN P21 & P. helicoides \\
\hline $\mathrm{X}-\mathrm{a}$ & B1e & F-I & - & - & - & - & - & $34(\mathrm{n} / \mathrm{a})$ & None & ++ & UKN P54 & P. arrhenomanes \\
\hline X-b & B1e & F-I & $26.5(1.3)$ & $\mathrm{m}(\mathrm{d})$ & $26.5(1.3)$ & $\mathrm{p}$ & 2.5 & $31.3(1.5)$ & None & ++ & UKN P11 & P. phragmitis \\
\hline$X-c$ & B1e & F-I & $25.5(1)$ & m (d) & $25(1)$ & $\mathrm{p}$ & 2.5 & $29(0.6)$ & None & ++ & CBS 117104 & P. phragmitis \\
\hline XII & $\mathrm{K}$ & G & n.d. & n.d. & n.d. & n.d. & n.d. & n.d. & Rosaceous & - & UKN P32 & P. citrinum \\
\hline XIII & A & $\mathrm{F}$ & - & - & - & - & - & $8.5(\mathrm{n} / \mathrm{a})$ & Narrow rosaceous & - & UKN P43 & P. porphyrae \\
\hline XIV & B1d & F-I & n.d. & n.d. & n.d. & n.d. & n.d. & n.d. & None & ++ & UKN P41 & P. inflatum \\
\hline
\end{tabular}


Table 3 - Comparison of diversity indices in oomycete communities from reed stands as revealed by baiting from dry and flooded sites using reed and oak baits

\begin{tabular}{|c|c|c|c|c|c|c|c|}
\hline \multirow[t]{2}{*}{ Community } & \multicolumn{2}{|c|}{ Species diversity } & \multicolumn{5}{|c|}{ Molecular diversity } \\
\hline & Species & Shared species & Simpson's D & Shannon-Wiener & Usable loci & Theta (s.D.) & $\mathrm{F}_{\mathrm{st}}$ \\
\hline Bait (dry) & 8 & 4 & $7.235^{\mathrm{a}}$ & $1.992^{\mathrm{b}}$ & 416 & $75.3(38)$ & $0.014(P>0.05)$ \\
\hline Bait (flooded) & 14 & & $10.22^{\mathrm{a}}$ & $2.415^{\mathrm{b}}$ & 398 & $67.8(33.5)$ & \\
\hline Bait (oak) & 13 & 3 & $8.292^{\mathrm{a}}$ & $2.277^{\mathrm{b}}$ & 419 & $81.6(40)$ & $0.276(P<0.001)$ \\
\hline Bait (reed) & 8 & & $5.125^{\mathrm{a}}$ & $1.820^{\mathrm{b}}$ & 430 & $35.1(18.2)$ & \\
\hline
\end{tabular}

baits. In addition, various diversity indices confirmed the differentiation between the communities from the different substrates (Table 3). However, the sequence divergence in$\operatorname{dex} \theta_{\pi}$ did not reflect the clear differentiation of communities from dry versus flooded habitats (Table 3), due to the high frequency of closely related taxa (e.g. I, I-a, I-b, or X-a, $\mathrm{X}-\mathrm{b}, \mathrm{X}-\mathrm{c}$ ) that all have been given species rank in our study. Therefore, the index, although a useful tool (Martin 2002; Arcate et al. 2006), might underrate community diversity and differentiation in certain cases; as repeatedly shown for various oomycete genera, even low degrees of ITS sequence divergence can be used to delineate ecologically, morphologically and pathologically distinct species (e.g. Nechwatal et al. 2005).

According to our data, the oomycete species detected in the investigated sites can clearly be subdivided into two major functional categories: (1) species not or loosely associated with common reed; and (2) species closely associated with reed. The first group comprises a set of species that, under the conditions studied, can be considered at least facultatively saprobic, with the dominating representatives being species from clades B2 and $\mathrm{K}$, which are generally considered to be non- or weakly pathogenic species (Lévesque \& De Cock 2004). In the baiting campaign, nine different members of these two clades alone were found (Table 1). They were almost exclusively isolated from oak baits, and did not cause any considerable damage to mature reed leaves, indicating the absence of a close association with reed, the dominating plant in the investigated sites. Although pathogenicity towards other plants cannot be excluded, together with members of other less abundant types (e.g. II, IV, XIII), these species are obviously colonising substrates consisting of various types of plant debris (e.g. fallen tree leaves, dead reed material, submerged macrophytes) during different stages of decay. The second group consists of a set of grass pathogens, belonging to clusters B1d and B1e of Lévesque \& De Cock (2004). In particular, P. phragmitis, among the most frequently occurring oomycetes, is considered an important factor in reed decline (Nechwatal et al. 2005). P. arrhenomanes (X-a), P. aff. inflatum (XIV), and the putative hybrid $(\mathrm{X}-\mathrm{b})$ are likely to be associated with reed. They are closely related to important grass pathogens (van der Plaats-Niterink 1981), and were shown to be pathogenic towards reed in our study. Accordingly, this group dominated the oomycete community caught with reed baits, indicating their ability to act as pathogens on this host. Interestingly, $P$. arrhenomanes was frequently isolated from cornfields adjacent to reed stands during a separate isolation campaign (J.N. unpubl.).

Pythium spp. from cluster B1e (and B1d) were among the dominating species in the two habitat types investigated within the reed belt. Four different members of these groups were identified in our study, all of which are likely to be closely associated with reed. The prevalence of these species might be favoured by a particularity of the plant community studied here, i.e. the strong predominance of a single plant species, Phragmites australis. Thus, reed stands can be considered natural monocultures similar to agricultural systems, favouring the development and performance of host-specific pathogens. This is particularly true when the primarily clonal reproduction strategy of reed is taken into account, leading to low genetic diversity within a stand. It has been shown for natural (forest) ecosystems that accumulation of specific Pythium spp. can occur beneath a plant species, and due to negative feedback, favour the establishment of other species (Packer \& Clay 2000). As littoral reed habitats are not suitable for the majority of plant species, negative feedback effects due to pathogen accumulation might become apparent as cycles of reed dieback (and progression), as observed for several European lakes for the past five decades (Brix 1999). These might correlate with the occurrence of water level fluctuations or flooding events, as shown in detail for P. phragmitis (Nechwatal et al. 2005, in press). According to the results of this study, a set of different, more or less closely related taxa rather than a single species can contribute to reed damage and decline phenomena in Lake Constance, with each species occupying a specific niche within the reed belt, and possibly being well-adapted to specific environmental conditions. Of these, P. phragmitis is the most abundant in flooded soils, while $P$. arrhenomanes seems to be an invading pathogen from adjacent agricultural sites, rather adapted to terrestrial sites. The putative hybrid, type X-b, thrives in flooded as well as in drier soils, and, according to recent field studies, seems to be a widely distributed, stable, and successful evolutionary unit (Nechwatal \& Mendgen 2007). Further studies should elucidate the specific ecological prevalence of each of these species, their population dynamics over several consecutive years, and the correlation between their abundance, environmental factors in the littoral, and the extent of reed damage observed. 


\section{Acknowledgements}

This study was funded by the Deutsche Forschungsgemeinschaft (DFG) as part of the Sonderforschungsbereich 454 ('Littoral Zone of Lake Constance').

\section{R E F E R E N C E S}

Arcate JM, Karp MA, Nelson EB, 2006. Diversity of peronosporomycete (oomycete) communities associated with the rhizosphere of different plant species. Microbial Ecology 51: 36-50.

Brasier CM, Jung T, 2003. Progress in understanding Phytophthora diseases of trees in Europe. In: McComb JA, Hardy GES, Tommerup IC (eds), Phytophthora in Forests and Natural Ecosystems. Second International IUFRO Working Party 7.02.09 Meeting, Albany, Australia, 30 Sep.-5 Oct., pp. 4-18.

Brix H, 1999. The European research project on reed die-back and progression (EUREED). Limnologica 29: 5-10.

Cavalier-Smith T, 1998. A revised six-kingdom system of life. Biological Reviews 73: 203-266.

Cooke DEL, Duncan JM, 1997. Phylogenetic analysis of Phytophthora species based on ITS1 and ITS2 sequences of the ribosomal RNA gene repeat. Mycological Research 101: 667-677.

Dick MW, 1971. The ecology of Saprolegniaceae in lentic and littoral muds with a general theory of fungi in the lake ecosystem. Journal of General Microbiology 65: 325-337.

Dick MW, 1990. Keys to Pythium. The author, Reading.

Dick MW, 2001. The Peronosporomycetes. In: McLaughlin DJ, McLaughlin EG, Lemke PA (eds), The Mycota, Vol. VII. Part A. Systematics and Evolution. Springer, Berlin, pp. 39-72.

Felsenstein J, 1995. PHYLIP (Phylogeny Inference Package) Version 3.5c Distributed by the author. Department of Genetics, University of Washington, Seattle.

Hardman JM, Dick MW, 1987. Short-term fluctuations in availability of Pythium propagules for isolation from soil. Transactions of the British Mycological Society 88: 29-39.

Haslam SM, 1972. Biological flora of the British Isles: Phragmites communis Trin. (Arundo phragmites L.?, Phragmites australis (Cav.) Trin. ex Steudel). Journal of Ecology 60: 585-610.

Hendrix FF, Campbell WA, 1973. Pythiums as plant pathogens. Annual Review of Phytopathology 11: 77-98.

Jung T, Blaschke H, Neumann P, 1996. Isolation, identification and pathogenicity of Phytophthora species from declining oak stands. European Journal of Forest Pathology 26: 253-272.

Lévesque CA, De Cock AWAM, 2004. Molecular phylogeny and taxonomy of the genus Pythium. Mycological Research 108: 1363-1383.

Martin AP, 2002. Phylogenetic approaches for describing and comparing the diversity of microbial communities. Applied Environmental Microbiology 68: 3673-3682.

Martin FN, 1992. Pythium. In: Singleton LL, Mihail JD, Rush CM (eds), Methods for Research on Soilborne Phytopathogenic Fungi. APS Press, St Paul, pp. 39-49.

Mills KE, Bever JD, 1998. Maintenance of diversity within plant communities: soil pathogens as agents of negative feedback. Ecology 79: 1595-1601.
Nechwatal J, Osswald W, 2001. Comparative studies on the fine root status of healthy and declining spruce and beech trees in the Bavarian Alps and occurrence of Phytophthora and Pythium species. Forest Pathology 31: 257-273.

Nechwatal J, Osswald W, 2003. Pythium montanum sp. nov., a new species from a spruce stand in the Bavarian Alps. Mycological Progress 2: 73-80.

Nechwatal J, Mendgen K, 2006a. Pythium litorale sp. nov., a new species from the littoral of Lake Constance, Germany. FEMS Microbiology Letters 255: 96-101.

Nechwatal J, Mendgen K, 2006b. Widespread detection of Phytophthora taxon salixsoil in the littoral zone of Lake Constance, Germany. European Journal of Plant Pathology 114: 261-264.

Nechwatal J, Mendgen K, 2007. Occurrence of natural hybridisation within reed-associated Pythium spp. In: McDonald B, Brunner P, Ceresini P, Lebeda A (eds), International Meeting on Population and Evolutionary Biology of Fungal Symbionts, Ascona, Switzerland, 29 Apr.-4 May 2007, p. 38.

Nechwatal J, Wielgoss A, Mendgen K, 2005. Pythium phragmitis sp. nov., a new species close to P. arrhenomanes as a pathogen of common reed (Phragmites australis). Mycological Research 109: 1337-1346.

Nechwatal J, Wielgoss A, Mendgen K. Flooding events and rising water temperatures increase the significance of the reed pathogen Pythium phragmitis as a contributing factor in the decline of Phragmites australis. Hydrobiologia, in press.

Newell SY, Fell JW, 1996. Cues for zoospore release by marine oomycotes in naturally decaying submerged leaves. Mycologia 88: 934-938.

Packer A, Clay K, 2000. Soil pathogens and spatial patterns of seedling mortality in a temperate tree. Nature London 404: 278-281.

Packer A, Clay K, 2004. Development of negative feedback during successive growth cycles of black cherry. Proceedings of the Royal Society London B 271: 317-324.

Paul B, 2003. Pythium carbonicum, a new species isolated from a spoil heap in northern France, the ITS region, taxonomy and comparison with related species. FEMS Microbiology Letters 219: 269-274.

Perrière G, Gouy M, 1996. WWW-Query: an on-line retrieval system for biological sequence banks. Biochimie 78: 364-369.

van der Plaats-Niterink AJ, 1981. Monograph of the genus Pythium. Studies in Mycology 21: 1-242.

Romero MA, Sanchez JE, Jiminez JJ, Belbahri L, Trapero A, Lefort F, Sanchez ME, 2007. New Pythium taxa causing root rot on Mediterranean Quercus species in South-west Spain and Portugal. Journal of Phytopathology 155: 289-295.

Schneider S, Roessli D, Excoffier L, 2000. Arlequin: a software for population genetics data analysis. Version 2.000. University of Geneva.

Waterhouse GM, 1968. The genus Pythium Pringsheim. Mycological Papers 110: 1-71.

White TJ, Bruns T, Lee S, Taylor J, 1990. Amplification and direct sequencing of fungal ribosomal RNA genes for phylogenetics. In: Innis MA, Gelfand DH, Sninsky JJ, White TJ (eds), PCR Protocols: a guide to methods and applications. Academic Press, San Diego, pp. 315-322. 